\title{
A Double-Blind Clinical Study to Investigate the Effects of a Fungal Protease Enzyme System on Metabolic, Hepato-renal, and Cardiovascular Parameters Following 30 Days of Supplementation in Active, Healthy Men
}

\author{
Mark L. Anderson
}

Received: 3 March 2011 / Accepted: 17 November 2011 /Published online: 13 December 2011

(C) The Author(s) 2011. This article is published with open access at Springerlink.com

\begin{abstract}
Research on the role of digestion in overall health has driven increasing interest in the use of digestive enzymes, which may improve nutrient absorption and reduce gastrointestinal symptoms. Sales of digestive aids and enzymes have grown over $8 \%$ in 2009 , with enzymes accounting for $\$ 69$ million of this growing category. Recent clinical research reported that acute dosing of Aminogen ${ }^{\circledR}$, a patented blend of digestive protease enzymes isolated from Aspergillus and blended with whey protein concentrate, increased the rate of protein absorption. The results indicated a faster rate of amino acid absorption reflected in significantly higher blood levels of amino acids, increased nitrogen retention, and significantly reduced levels of C-reactive protein. Few studies, however, have examined the safety of repeated dosing of oral enzymes with an appropriate substrate. The purpose of this study, therefore, was to evaluate basic measures of clinical safety during 30 days of continuous, repeated dosing of Aminogen ${ }^{\circledR}$ and whey protein supplementation in healthy, active men maintaining a regimen of resistance training. Parameters evaluated include various markers of general physical health, metabolic function, hepato-renal function, and cardiovascular health including fasting blood lipids. Forty healthy, resistance-trained men $(27.1 \pm 7.9$ years $)$ were recruited for this double-blind, randomized study. Group A ingested two 40-g doses of whey protein per day containing Aminogen ${ }^{\circledR}$. Group B ingested two 40-g doses
\end{abstract}

M. L. Anderson $(\triangle)$

R\&D Department, Triarco Industries, LLC,

400 Hamburg Turnpike,

Wayne, NJ 07470, USA

e-mail: Mark.Anderson@triarco.com of whey protein per day. No significant changes were noted in measures of general physical health, metabolic function, cardiovascular health, and hepato-renal function within or between groups. However, total cholesterol, LDL cholesterol, and serum calcium significantly increased $(P<0.05)$ in group B. In group A, whey protein containing Aminogen ${ }^{\circledR}$ was well tolerated with no adverse reactions reported. No differences in serum markers of clinical safety and an improved blood lipid profile are also reported.

Keywords Aminogen ${ }^{\circledR}$. Fungal enzyme system $\cdot$ Fungal protease $\cdot$ Cholesterol $\cdot$ Safety $\cdot$ Aspergillus

\section{Introduction}

Research on the importance of digestion for overall health has driven increasing interest in the use of digestive enzymes, which may improve nutrient absorption and reduce gastrointestinal symptoms [1]. Sales of digestive aids and enzymes have grown over $8 \%$ in the last year, with enzymes accounting for $\$ 69$ million of this growing category [2]. Although supplementing with digestive enzymes is becoming increasingly popular, there is little clinical data available regarding the safety of oral fungal proteases as digestive aids or dietary supplements. This may be due in part to confusion regarding effective dose and activity, which is substrate specific and temperature sensitive, after oral dosing. Digestive enzyme supplementation may also simply be presumed to be safe, since enzymes have been used in food processing and as food additives for almost a century. The heat generated in food processing and cooking typically destroys enzyme activity 
before ingestion [3]. Conversely, activity of enzymes for dietary supplementation should be intact to aid in digestion when taken orally. Recent clinical research has shown that Aminogen ${ }^{\circledR}$, a patented oral fungal protease blend, maintains activity after oral dosing. Acute dosing of Aminogen ${ }^{\circledR}$ with whey protein concentrate was effective for increasing the rate of protein absorption [4]. Forty healthy males were divided into two groups and received either $50 \mathrm{~g}$ whey protein concentrate $(80 \%$ protein) or $50 \mathrm{~g}$ of whey protein concentrate with Aminogen ${ }^{\circledR}$. The results indicated a faster rate of amino acid absorption reflected in significantly higher blood levels of amino acids and increased nitrogen retention in the Aminogen ${ }^{\circledR}$ group; significant reductions in $\mathrm{C}$-reactive protein levels were also reported. However, no data have been reported regarding the basic clinical safety from repeated oral dosing of the protease blend with an appropriate substrate. The purpose of this study, therefore, was to evaluate basic measures of clinical safety after combining Aminogen ${ }^{\circledR}$ and whey protein supplementation for 30 days of continuous dosing in healthy, active men maintaining a regimen of resistance training. Parameters evaluated include changes in various markers of general physical health, metabolic function, hepato-renal function, and cardiovascular health including fasting blood lipids. It is hypothesized that the addition of Aminogen ${ }^{\circledR}$ to whey protein will be well tolerated as indicated by compliance, absence of adverse events, non-significant changes in hemodynamic parameters, and normal ranges of all clinical chemistry parameters evaluated when compared to whey protein alone.

\section{Methods}

\section{Study Design}

This investigation was conducted in compliance with Good Clinical Practices, approved by an Institutional Review Board, and required the recruitment of two groups of healthy, male subjects. Following a 10-h fast, participants were assessed for resting heart rate, blood pressure weight and body mass index. Participants then donated a fasting blood sample for standard serum clinical chemistry analyses. Upon completing baseline testing, participants were assigned in a double-blind fashion to one of two treatment groups. After completing 4 weeks of a resistance training program, participants returned for a post-testing session identical to their baseline testing session. Body weight and hemodynamic and clinical chemistry data were statistically evaluated for significant differences at a significance level of 0.05 . Subjects with incomplete data sets would be dropped, and no incomplete data sets were used for statistical analyses.
Subjects

A priori power analysis for this design was done based on detecting 1-kg lean mass change (delta) between groups. At a $5 \%$ level of significance, a sample size of 20 subjects per group yields an acceptable power $(>0.75)$ for delta values of 0.75 to 1.25 . Forty healthy men between the ages of 18 and 45 years were recruited and randomized into two parallel groups (A \& B) of 20 subjects each and matched according to age, weight, body mass index, and exercise background. Twenty participants completed the study in group A, and 16 participants completed the study in group B. Data for the 36 participants that completed the study were used for all statistical analyses including baseline total mean data (Table 1). Inclusion criteria for all participants required them to: (1) be in good health according to health history questionnaire and routine blood chemistries; (2) have a body mass index of 20-35. (3) have been resistance training regularly (defined as completing three workouts per week on average) for at least 2 years according to completed physical activity questionnaire; (4) be willing and able to comply with the supplement and training protocol; and (5) have reviewed, signed, and dated the informed consent forms provided by the investigator to participate in the study. This subject profile was selected since Aminogen ${ }^{\circledR}$ has gained popularity in the sports nutrition industry.

Participants were excluded if they: (1) were currently participating or had participated in other research studies within the last 30 days; (2) had gained or lost more than $10 \mathrm{lb}$ in the last 30 days; (3) did not verbally express comprehension of the informed consent document; (4) reported past or current use of anabolic steroids, IGF-1, growth hormone, or any other anabolic drugs within the past year, as well as patients who had taken thyroid, hyperlipidemic, hypoglycemic, antihypertensive, anti-coagulant, or androgenic medications; (5) reported having taken or were currently taking ergogenic levels of nutritional supplements that may affect muscle mass (e.g., creatine, HMB) or anabolic/catabolic hormone levels (androstenedione, DHEA, etc.) within 6 weeks prior to the start of the study; and (6) reported to have a known allergy to any ingredients in Aminogen ${ }^{\circledR}$ or whey protein. Finally, participants were excluded if they were receiving medical treatment including: (but not limited to) receiving prescription medications for or being diagnosed with any form of pulmonary, metabolic, psychiatric, neuromuscular, orthopedic, or cardiovascular condition which may alter their normal physiological adaptation to nutritional supplementation and resistance training.

\section{Familiarization Session}

All participants were familiarized with the study procedures and assessed for baseline height and weight after submitting 
Table 1 Baseline (T0) anthropometric, body composition, biochemical parameters, and dietary analysis for the Aminogen ${ }^{\circledR}+$ whey protein (group A) and whey protein (group B) subject groups

\begin{tabular}{|c|c|c|c|c|}
\hline Demographics & Total mean $(n=36)$ & Group A $(n=20)$ & Group B $(n=16)$ & $p$ value \\
\hline Age (years) & $27.1 \pm 7.9$ & $27.8 \pm 8.2$ & $26.4 \pm 7.6$ & 0.61 \\
\hline Height (cm) & $179 \pm 6$ & $178 \pm 5$ & $179 \pm 6$ & 0.58 \\
\hline Weight (kg) & $82.2 \pm 10.8$ & $82.0 \pm 7.6$ & $82.4 \pm 14.1$ & 0.91 \\
\hline Body mass index $\left(\mathrm{kg} \mathrm{m}^{-2}\right)$ & $25.7 \pm 2.6$ & $25.8 \pm 1.9$ & $25.5 \pm 3.4$ & 0.78 \\
\hline Resting heart rate (bpm) & $69.5 \pm 9.3$ & $69.8 \pm 10.0$ & $69.1 \pm 8.7$ & 0.83 \\
\hline Systolic blood pressure $(\mathrm{mmHg})$ & $121.3 \pm 11.6$ & $123.7 \pm 11.5$ & $118.4 \pm 11.3$ & 0.17 \\
\hline Diastolic blood pressure $(\mathrm{mmHg})$ & $75.7 \pm 8.6$ & $78.9 \pm 7.9^{\mathrm{a}}$ & $71.8 \pm 7.9$ & 0.01 \\
\hline Biochemical parameters & Total Mean $(n=36)$ & Group A $(n=20)$ & Group B $(n=16)$ & $p$ value \\
\hline Total cholesterol $\left(\mathrm{mmol} \mathrm{L}^{-1}\right)$ & $3.9 \pm 0.9$ & $4.1 \pm 0.8$ & $3.7 \pm 0.9$ & 0.10 \\
\hline HDL cholesterol $\left(\mathrm{mmol} \mathrm{L}^{-1}\right)$ & $1.3 \pm 0.5$ & $1.2 \pm 0.4$ & $1.4 \pm 0.7$ & 0.37 \\
\hline LDL cholesterol $\left(\mathrm{mmol} \mathrm{L}^{-1}\right)$ & $2.3 \pm 0.8$ & $2.5 \pm 0.8$ & $2.1 \pm 0.8$ & 0.15 \\
\hline Triglycerides $\left(\mathrm{mmol} \mathrm{L}^{-1}\right)$ & $0.84 \pm 0.36$ & $0.9 \pm 0.5$ & $0.76 \pm 0.20$ & 0.21 \\
\hline Glucose $\left(\mathrm{mmol} \mathrm{L}^{-1}\right)$ & $4.9 \pm 0.4$ & $5.0 \pm 0.4^{\mathrm{a}}$ & $4.7 \pm 0.3$ & 0.006 \\
\hline Potassium $\left(\mathrm{U} \mathrm{L}^{-1}\right)$ & $4.27 \pm 0.29$ & $4.33 \pm 0.33$ & $4.19 \pm 0.22$ & 0.16 \\
\hline Calcium (mg dL $\left.{ }^{-1}\right)$ & $9.5 \pm 0.27$ & $9.6 \pm 0.24$ & $9.4 \pm 0.31$ & 0.23 \\
\hline Alkaline phosphatase $\left(\mathrm{U} \mathrm{L}^{-1}\right)$ & $69.0 \pm 15.0$ & $71.3 \pm 15.8$ & $66.3 \pm 14.0$ & 0.33 \\
\hline AST $\left(\mathrm{IU} \mathrm{L}^{-1}\right)$ & $28.9 \pm 17.8$ & $33.1 \pm 22.1$ & $23.6 \pm 8.1$ & 0.11 \\
\hline ALT (IU L $\left.{ }^{-1}\right)$ & $28.9 \pm 21.6$ & $35.7 \pm 26.5^{\mathrm{a}}$ & $20.3 \pm 7.7$ & 0.03 \\
\hline $\mathrm{BUN}\left(\mathrm{mg} \mathrm{dL}^{-1}\right)$ & $17.6 \pm 4.5$ & $17.7 \pm 4.92$ & $17.6 \pm 3.98$ & 0.99 \\
\hline Creatinine $\left(\mathrm{mg} \mathrm{dL}^{-1}\right)$ & $1.80 \pm 4.47$ & $2.32 \pm 5.2$ & $1.15 \pm 0.17$ & 0.37 \\
\hline BUN/creatinine & $15.2 \pm 3.3$ & $15.1 \pm 3.7$ & $15.4 \pm 2.8$ & 0.76 \\
\hline Total protein $\left(\mathrm{U} \mathrm{L}^{-1}\right)$ & $7.1 \pm 0.39$ & $7.1 \pm 0.42$ & $7.0 \pm 0.36$ & 0.73 \\
\hline Dietary intake & Total mean $(n=36)$ & Group A $(n=20)$ & Group B $(n=16)$ & $p$ value \\
\hline Caloric intake (kcal/day) & $2,662 \pm 670$ & $2,609 \pm 581$ & $2,729 \pm 782$ & 0.60 \\
\hline Caloric intake (kcal/kg/day) & $32.7 \pm 8.2$ & $32.1 \pm 7.9$ & $33.4 \pm 8.7$ & 0.63 \\
\hline Carbohydrate (g/kg/day) & $3.3 \pm 1.0$ & $3.2 \pm 1.1$ & $3.4 \pm 0.9$ & 0.47 \\
\hline Protein (g/kg/day) & $2.9 \pm 1.0$ & $2.8 \pm 0.7$ & $3.0 \pm 1.3$ & 0.64 \\
\hline Fat (g/kg/day) & $0.9 \pm 0.3$ & $0.92 \pm 0.3$ & $0.88 \pm 0.4$ & 0.74 \\
\hline
\end{tabular}

All data are presented as means \pm SD at baseline. Significance level was set at 0.05

a completed, signed Informed Consent Agreement. Standing height was measured by a wall-mounted stadiometer while body mass was assessed using SECA 767 Medical scale $( \pm 0.1 \mathrm{~kg})$. All participants met with the study dietitian, who provided education and background on how to properly complete a 3-day food intake record based on household measures. The initial baseline testing session was scheduled no less than 4 days and typically no more than 2 weeks after completion of familiarization.

\section{Procedures}

Participants were instructed to avoid heavy exercise for the $48 \mathrm{~h}$ prior to their scheduled initial testing session. Participants also completed a food intake record consisting of all food and fluid intake over a 3-day period consisting of at least two weekdays and one weekend day. All baseline food intake data were entered into Nutribase IV Nutrition
Software, CyberSoft, Inc. (Phoenix, AZ) and analyzed for average energy and macronutrient intake by the study dietitian. Participants were instructed to maintain consistent eating habits relative to energy and macronutrient intake throughout the study. Additional 3-day diet records were analyzed by the study dietitian at week 2 and during posttesting (week 4) to verify that eating habits remained consistent throughout the study. No assessment was made for over- or underreporting.

Upon arrival and at all testing sessions, heart rate was determined by palpation of the radial artery, and blood pressure was taken with an automated sphygmomanometer (LifeSource UA-851V). Body weight was determined using a SECA 767 Medical scale $( \pm 0.1 \mathrm{~kg})$.

Prior to arriving for all testing sessions, participants were asked to observe a 10-h fast (no eating of any food or drinking of any fluid with calories). To control for any diurnal variations in blood markers, all testing sessions 
were scheduled at similar times. A fasting blood sample $(\sim 15 \mathrm{~mL})$ was collected from an antecubital vein into serum separation tubes (Vacutainer ${ }^{\mathrm{TM}}$ Becton Dickson) using standard phlebotomy techniques. All blood samples were centrifuged $(3,000 \times g)$ for 10 min using a standard benchtop centrifuge; serum was sent to Quest Diagnostics Laboratory (Pittsburgh, PA) for lipid and metabolic automated chemistry profiles. Lipid profile included: total cholesterol, LDL cholesterol, HDL cholesterol, and total cholesterol/HDL and triglycerides. Metabolic profile included: sodium, potassium, chloride, carbon dioxide, calcium, albumin, bilirubin, globulin, albumin/globulin, alkaline phosphatase, glucose, blood urea nitrogen (BUN), creatinine, BUN/ creatinine, total protein, glomerular filtration rate, kidney and liver enzymes (aspartate aminotransferase, alanine aminotransferase).

\section{Supplementation Protocol}

Single doses of either (a) whey protein concentrate, blended with 3\% Aminogen ${ }^{\circledR}$ (Triarco Industries, Wayne, NJ) and $0.2 \%$ Natural Vanilla (Craftmaster) or (b) $50 \mathrm{~g}$ whey protein concentrate blended with $0.2 \%$ Natural Vanilla was prepackaged, stamped with either an A or a B and shipped to the facilities of Applied Health Sciences clinical research organization (Fairlawn, $\mathrm{OH}$ ) where the study was conducted. No solubilizers, emulsifiers, or other excipients were added to the protein concentrate. The contents of the packets were blinded to the testing facility staff as well as the subjects. Subjects were matched into parallel groups according to body mass index, weight, age, and resistance experience. They were then randomly assigned to ingest either packet A or packet B twice a day for the duration of the study. One packet was taken $30 \mathrm{~min}$ before resistance training, and another one was taken immediately after. On non-training days, both groups ingested their respective packets at breakfast and before bed. All packets were prepared by mixing the entire contents with $8-10 \mathrm{oz}$ of water. The whey protein for both groups was Avonlac 180 (Glanbia Nutritionals, Twin Falls, ID) consisting of $80 \%$ protein, less than $10 \%$ fat, less than $5 \%$ moisture, less than $5 \%$ minerals, and 5\% lactose. Consumption was matched for total caloric content and ingested at the same time of day during the study. Subjects were contacted by a study dietician weekly to monitor compliance with the supplementation protocol and complete a questionnaire (by phone) to monitor changes in appetite, stomach distress, sleep habits, muscle soreness and cramping, irritability, headache, general attitude, appetite, and any other idiosyncratic responses to the supplementation and training protocol. In addition to the weekly phone calls, participant compliance was monitored by having participants return empty packets of their supplement during post-testing (week 4). Compliance to the supplementation protocol was greater than $90 \%$ for all subjects.

\section{Resistance Training Protocol}

To get an accurate representation of current physical activity habits, all participants were asked and monitored to follow a 4-day split-body resistance training program [5]. The workout, which consisted of 12 exercises, involved upper and lower body training twice per week using a 4day split (i.e., upper body on Monday, lower body on Tuesday, upper body on Thursday, lower body on Friday), increasing gradually in intensity and volume. Lower body exercises included leg extension, leg curl, barbell or Smithmachine squat, lunge, dead lift, and calf raise. Upper body exercises included the lat pull down, seated row, triceps press down, bench press, shoulder press, and dips. For the first 2 weeks, participants completed four sets of 12 to 15 repetitions at intensities equivalent to 10 - to 12-repetition maximum loads. For the final 2 weeks, participants completed four sets of six to eight repetitions at intensities equivalent to a six- to eight-repetition maximum load. Participants rested for $2 \mathrm{~min}$ between each set of exercise and 2 min between each exercise. Training was documented in training logs and signed off by fitness instructors and/or gym personnel at the patient's local training facility.

\section{Statistical Analysis}

All data were first tested for normality by the Shapiro-Wilk test and standardized skewness and kurtosis $z$ scores. If normality was violated, data were log transformed. Homogenous baseline samples were determined by using an independent samples $t$ test on all descriptive data (age, height, weight) and body mass index variables. If baseline differences were found, data were analyzed using ANCOVA statistics with that baseline variable as a covariate. Separate 2 (group) $\times 2$ (time) mixed factorial analysis of variance with repeated measures on test to determine main and interactive effects with Bonferroni corrections applied to all confidence intervals was used for all dependent variables. When interactive effects were found, simple pairwise comparisons were used to identify all differences. A significance value of 0.05 was applied for all statistical decisions. No data sets from dropouts were included in the statistical analyses.

\section{Results}

Baseline Values

Baseline values for all participants were computed and compared to ensure homogeneity of the groups. As 
indicated in Table 1, no significant $(p>0.05)$ baseline differences were reported in criterion variables with the exception of resting diastolic blood pressure (group $\mathrm{A}=$ $78.9 \pm 7.9$ vs. group $\mathrm{B}=71.8 \pm 7.9 \mathrm{mmHg} ; p<0.05)$, alanine aminotransferase (ALT) (group $\mathrm{A}=35.7 \pm 26.5$ vs. group $\mathrm{B}=$ $20.3 \pm 7.7 ; p<0.05$ ), and fasting glucose (group $\mathrm{A}=5.0 \pm$ $0.4 \mathrm{mmol} \mathrm{L}^{-1}$ vs. group $\mathrm{B}=4.7 \pm 0.3 ; p<0.01$ ).

\section{Dietary Intake}

Absolute (kilocalories per day) and relative (kilocalories per kilogram per day) average energy intake per person changed from 2,662 kcals d ${ }^{-1}$ at baseline (T0) to 2,597 kcals d ${ }^{-1}$ at the end of the 4-week protocol (T1), $p=0.047$. This reduction was estimated to be $65 \mathrm{kcals} \mathrm{d}^{-1}$. Average carbohydrate intake changed from $3.3 \pm 1.0 \mathrm{~g} \mathrm{CHO} \mathrm{kg} \mathrm{d}^{-1}$ at $\mathrm{T} 0$ to $3.2 \pm$ $0.97 \mathrm{~g} \mathrm{CHO} \mathrm{kg} \mathrm{d}^{-1}$ at $\mathrm{T} 1(p<0.05)$. Average daily protein intake changed from $2.9 \pm 0.99 \mathrm{~g}^{\mathrm{PRO}} \mathrm{kg} \mathrm{d}^{-1}$ at $\mathrm{T} 0$ to $3.1 \pm$ $1.01 \mathrm{~g} \mathrm{PRO} \mathrm{kg} \mathrm{d}^{-1}$ at T1 $(p<0.001)$. No significant $(p=0.05)$ interactive effects, group $(\mathrm{G}) \times$ time $(T)$, were found for relative carbohydrate and protein intake. Average fat intake changed from $0.9 \pm 0.35 \mathrm{~g}_{\text {fat }} \mathrm{kg} \mathrm{d}^{-1}$ at $\mathrm{T} 0$ to $0.85 \pm 0.35 \mathrm{~g}$ fat $\mathrm{kg} \mathrm{d}^{-1}$. A significant $(p=0.05)$ interaction was found for fat intake normalized to body mass in kilograms as the relative fat intake remained constant in group B and was $11 \%$ lower in group A at T1 $(p=0.044)$.

\section{Adverse Events and Compliance}

Adverse event forms were provided by the clinical research facility. Participants were required to submit adverse event reports at the conclusion of the study or upon withdrawal of the study for any reason. Some episodes of upset stomach, nausea, and headache were reported to the study dietitian from both groups but none serious enough to require dropping out of the study. No adverse event forms were submitted from supplementation was reported from either group. Compliance to the supplementation protocol was reported to be greater than $90 \%$ as indicated by returned packets and weekly follow-up by the fitness staff. Similarly, compliance to the resistance protocol was recorded by fitness staff and was reported to be greater than $90 \%$ as four participants reported missing no more than two workouts. Two subjects in group B did not finish due to injury and illness. Two others in group B were eliminated due to incomplete data sets.

\section{Markers of Metabolic and Cardiovascular Health}

No significant $(p>0.05)$ main or interactive effects $(G \times T)$ were reported for resting heart rate, systolic blood pressure, and diastolic blood pressure. Although an interactive effect for diastolic blood pressure began to approach significance
$(G \times T ; p=0.06)$, all values for both groups A and B reported diastolic blood pressure values in normally expected ranges (Table 2). No significant $(p=0.05)$ changes were reported for serum levels of HDL cholesterol, triglycerides, and glucose and the ratio of total and HDL cholesterol. A significant $(p=0.05)$ interactive effect was found for serum total cholesterol values. Table 2 shows serum levels did not change for group A while a significant $(p=0.05)$ increase in total cholesterol values was reported in group B (whey protein only). Similar findings were also reported for LDL cholesterol as serum changes in group A were not significant $(p=0.05)$, but LDL cholesterol values in group $\mathrm{B}$ increased significantly $(p=0.05)$.

\section{Other Serum Clinical Markers}

No significant $(p>0.05)$ interactive effects were found for the following variables: sodium $(G \times T ; p=0.87)$, chloride $(G \times T ; p=0.82)$, carbon dioxide $(G \times T ; p=0.84)$, bilirubin $(G \times T ; p=0.91)$, albumin $(G \times T ; p=0.59)$, globulin $(G \times T$; $p=0.61)$, albumin/globulin $(G \times T ; p=0.70)$, glomerular filtration rate $(G \times T ; p=0.38)$, alkaline phosphatase $(G \times$ $T ; p=0.44)$, AST $(G \times T ; p=0.23)$, blood urea nitrogen $(G \times$ $T ; p=0.19)$, and total protein $(G \times T ; p=0.51)$. Main effects for time but no significant $(p=0.05) G \times T$ interaction effects were found for creatinine, BUN/creatinine, and albumin. All values, however, remained within expected clinical norms. Significant $(p=0.05) G \times T$ interaction effects were found for serum potassium and calcium (Table 3). All effects were found to remain within expected clinical values.

\section{Discussion}

The purpose of this study was to evaluate parameters of general physical health, metabolic function, cardiovascular health, and hepato-renal function when adding a specific fungal protease enzyme system to twice daily $(80 \mathrm{~g}$ per day total) whey protein supplementation in healthy, active participants maintaining a regimen of resistance training. A number of previous reports have suggested that in an independent fashion, supplementation with whey protein [6-9] and fungal proteases [10, 11] may confer favorable health outcomes. It was initially hypothesized that the fungal protease addition to whey protein would favorably impact cardiovascular responses without instigating any unfavorable changes in glucose and lipid panels as well as markers of kidney, liver, and general metabolic function. The primary findings from this study demonstrate that $40-\mathrm{g}$ doses of whey protein, twice a day, containing 3\% Aminogen ${ }^{\circledR}$ are well tolerated as none of the parameters evaluated including the clinical chemistry profiles were negatively 
Table 2 Metabolic and cardiovascular health marker changes for the Aminogen ${ }^{\mathbb{R}}+$ whey protein (group A) and whey protein (group B) subject groups

All data are presented as group means \pm standard deviation for week 0 (T0) and week 4 (T1) of the protocol. Individual main effects for time are provided as within-group $p$ values. Group $\times$ time interaction effects are provided as $G \times T p$ values.

Between-group significance indicators represent the change from T0 to T1. Significance level was 0.05

${ }^{\mathrm{a}}$ Different from baseline ${ }^{\mathrm{b}}$ Different than group A

\begin{tabular}{|c|c|c|c|c|c|c|}
\hline \multirow[t]{2}{*}{ Variable } & \multirow[t]{2}{*}{ Group } & \multirow{2}{*}{$\begin{array}{l}\text { T0 } \\
\text { Week } 0\end{array}$} & \multirow{2}{*}{$\begin{array}{l}\text { T1 } \\
\text { Week } 4\end{array}$} & \multicolumn{3}{|l|}{$p$ value } \\
\hline & & & & Within group & Time & $G \times T$ \\
\hline Resting HR (bpm) & $\begin{array}{l}\text { A } \\
\text { B }\end{array}$ & $\begin{array}{l}69.8 \pm 10.0 \\
69.1 \pm 8.7\end{array}$ & $\begin{array}{l}69.2 \pm 7.4 \\
68.4 \pm 10.6\end{array}$ & $\begin{array}{l}0.74 \\
0.71\end{array}$ & 0.62 & 0.97 \\
\hline Systolic BP (mmHg) & $\begin{array}{l}\text { A } \\
\text { B }\end{array}$ & $\begin{array}{l}124 \pm 11.5 \\
118 \pm 11.3\end{array}$ & $\begin{array}{l}126 \pm 10.6 \\
122 \pm 11.0\end{array}$ & $\begin{array}{l}0.33 \\
0.83\end{array}$ & 0.07 & 0.67 \\
\hline Diastolic BP (mmHg) & $\begin{array}{l}\text { A } \\
\text { B }\end{array}$ & $\begin{array}{l}78.9 \pm 7.9 \\
71.8 \pm 7.9\end{array}$ & $\begin{array}{l}77.5 \pm 8.9 \\
74.1 \pm 7.9\end{array}$ & $\begin{array}{l}0.34 \\
0.06\end{array}$ & 0.59 & 0.06 \\
\hline Total cholesterol $\left(\mathrm{mmol} \mathrm{L}^{-1}\right)$ & $\begin{array}{l}\text { A } \\
\text { B }\end{array}$ & $\begin{array}{l}4.1 \pm 0.8 \\
3.7 \pm 0.9\end{array}$ & $\begin{array}{l}4.1 \pm 1.0 \\
4.1 \pm 0.8^{\mathrm{ab}}\end{array}$ & $\begin{array}{r}0.76 \\
<0.05\end{array}$ & 0.09 & $<0.05$ \\
\hline LDL cholesterol $\left(\mathrm{mmol} \mathrm{L}^{-1}\right)$ & $\begin{array}{l}\text { A } \\
\text { B }\end{array}$ & $\begin{array}{l}2.51 \pm 0.82 \\
2.10 \pm 0.81\end{array}$ & $\begin{array}{l}2.46 \pm 0.94 \\
2.53 \pm 0.94^{\mathrm{ab}}\end{array}$ & $\begin{array}{r}0.74 \\
<0.05\end{array}$ & 0.12 & 0.05 \\
\hline HDL cholesterol $\left(\mathrm{mmol}^{-1}\right)$ & $\begin{array}{l}\text { A } \\
\text { B }\end{array}$ & $\begin{array}{l}1.22 \pm 0.41 \\
1.39 \pm 0.69\end{array}$ & $\begin{array}{l}1.20 \pm 0.39 \\
1.20 \pm 0.37\end{array}$ & $\begin{array}{l}0.55 \\
0.29\end{array}$ & 0.20 & 0.29 \\
\hline Total Chol/HDL & $\begin{array}{l}\text { A } \\
\text { B }\end{array}$ & $\begin{array}{l}5.1 \pm 7.7 \\
3.0 \pm 1.0\end{array}$ & $\begin{array}{l}4.5 \pm 5.2 \\
4.4 \pm 4.2\end{array}$ & $\begin{array}{l}0.36 \\
0.22\end{array}$ & 0.49 & 0.11 \\
\hline Triglycerides $\left(\mathrm{mmol} \mathrm{L}^{-1}\right)$ & $\begin{array}{l}\text { A } \\
\text { B }\end{array}$ & $\begin{array}{l}0.90 \pm 0.45 \\
0.76 \pm 0.20\end{array}$ & $\begin{array}{l}0.95 \pm 0.46 \\
0.80 \pm 0.23\end{array}$ & $\begin{array}{l}0.49 \\
0.51\end{array}$ & 0.35 & 0.91 \\
\hline Glucose $\left(\mathrm{mmol} \mathrm{L}^{-1}\right)$ & $\begin{array}{l}\text { A } \\
\text { B }\end{array}$ & $\begin{array}{l}5.02 \pm 0.36 \\
4.70 \pm 0.28\end{array}$ & $\begin{array}{l}4.84 \pm 0.58 \\
4.70 \pm 0.40\end{array}$ & $\begin{array}{l}0.18 \\
0.95\end{array}$ & 0.32 & 0.28 \\
\hline
\end{tabular}

affected. This is also supported by no adverse events being reported throughout the 4-week study period.

There were surprising findings regarding significant main and interactive effects reported for total cholesterol and LDL cholesterol (Table 2). Similarly, interactive effects for diastolic blood pressure strongly approached significance $(p=0.06)$ and are worth discussing (Table 2). Interestingly, for all of these variables, significant increases were shown to occur or were very close to being significant (diastolic blood pressure; $p=0.06$ ) for only group $\mathrm{B}$, the whey protein group, while no such changes were seen in group A, the Aminogen ${ }^{\circledR}+$ whey protein group. Careful interpretation of these findings is suggested, however, due to the fact that all significant changes still resulted in values which remained within clinically accepted ranges (Table 2). This change could be partially explained by a significant increase in dietary fat, but this was not reported in either group. Consumption of fat significantly $(p=0.05)$ decreased
Table 3 Selected clinical markers of safety for the Aminogen ${ }^{\circledR}+$ whey protein (group A) and whey protein (group B) subject groups

All data are presented as group means \pm standard deviation for week 0 (T0) and week 4 (T1) of the protocol. Individual main effects for time are provided as within-group $p$ values. Group $\times$ time interaction effects are provided as $G \times T p$ values. Between-group significance indicators represent the change from T0 to T1. Significance level was 0.05 [13]

${ }^{\mathrm{a}}$ Different from baseline

${ }^{\mathrm{b}}$ Different than group B

\begin{tabular}{|c|c|c|c|c|c|c|}
\hline \multirow[t]{2}{*}{ Variable } & \multirow[t]{2}{*}{ Group } & \multirow[t]{2}{*}{ Week 0} & \multirow[t]{2}{*}{ Week 4} & \multicolumn{3}{|l|}{$p$ value } \\
\hline & & & & Within group & Time & $G \times T$ \\
\hline Potassium $\left(\mathrm{U} \mathrm{L}^{-1}\right)$ & $\begin{array}{l}\text { A } \\
\text { B }\end{array}$ & $\begin{array}{l}4.33 \pm 0.33 \\
4.19 \pm 0.22\end{array}$ & $\begin{array}{l}4.25 \pm 0.24 \\
4.34 \pm 0.30\end{array}$ & $\begin{array}{l}0.23 \\
0.15\end{array}$ & 0.57 & 0.05 \\
\hline Calcium & $\begin{array}{l}\text { A } \\
\text { B }\end{array}$ & $\begin{array}{l}9.6 \pm 0.24 \\
9.4 \pm 0.31\end{array}$ & $\begin{array}{l}9.5 \pm 0.22 \\
9.6 \pm 0.25^{\mathrm{ab}}\end{array}$ & $\begin{array}{r}0.62 \\
<0.05\end{array}$ & 0.07 & $<0.05$ \\
\hline Alkaline phosphatase $\left(\mathrm{U} \mathrm{L}^{-1}\right)$ & $\begin{array}{l}\text { A } \\
\text { B }\end{array}$ & $\begin{array}{l}71.3 \pm 15.8 \\
66.3 \pm 14.0\end{array}$ & $\begin{array}{l}71.3 \pm 18.9 \\
64.3 \pm 17.3\end{array}$ & $\begin{array}{l}0.24 \\
0.08\end{array}$ & 0.46 & 0.44 \\
\hline $\operatorname{AST}\left(\mathrm{U} \mathrm{L}^{-1}\right)$ & $\begin{array}{l}\text { A } \\
\text { B }\end{array}$ & $\begin{array}{l}33.1 \pm 22.1 \\
23.6 \pm 8.1\end{array}$ & $\begin{array}{l}27.2 \pm 19.0 \\
22.3 \pm 5.8\end{array}$ & $\begin{array}{l}0.08 \\
0.48\end{array}$ & 0.08 & 0.23 \\
\hline $\operatorname{ALT}\left(\mathrm{U} \mathrm{L}^{-1}\right)$ & $\begin{array}{l}\text { A } \\
\text { B }\end{array}$ & $\begin{array}{l}35.7 \pm 26.5 \\
20.3 \pm 7.7\end{array}$ & $\begin{array}{l}32.7 \pm 25.4 \\
22.6 \pm 9.3\end{array}$ & $\begin{array}{l}0.16 \\
0.23\end{array}$ & 0.78 & 0.07 \\
\hline $\mathrm{BUN}\left(\mathrm{mg} \mathrm{dL}^{-1}\right)$ & $\begin{array}{l}\text { A } \\
\text { B }\end{array}$ & $\begin{array}{l}17.7 \pm 4.92 \\
17.6 \pm 0.98\end{array}$ & $\begin{array}{l}19.3 \pm 5.4 \\
17.5 \pm 3.7\end{array}$ & $\begin{array}{l}0.07 \\
0.90\end{array}$ & 0.26 & 0.19 \\
\hline Creatinine $\left(\mathrm{mg} \mathrm{dL}^{-1}\right)$ & $\begin{array}{l}\text { A } \\
\text { B }\end{array}$ & $\begin{array}{l}2.32 \pm 5.2 \\
1.15 \pm 0.17\end{array}$ & $\begin{array}{l}2.28 \pm 5.2^{\mathrm{ab}} \\
1.10 \pm 0.14\end{array}$ & $\begin{array}{c}<0.001 \\
0.65\end{array}$ & $<0.005$ & 0.60 \\
\hline BUN/creatinine & $\begin{array}{l}\text { A } \\
\text { B }\end{array}$ & $\begin{array}{l}15.1 \pm 3.7 \\
15.4 \pm 2.8\end{array}$ & $\begin{array}{l}17.2 \pm 4.6 \\
15.8 \pm 3.1\end{array}$ & $\begin{array}{l}0.20 \\
0.65\end{array}$ & $<0.05$ & 0.15 \\
\hline Total protein $\left(\mathrm{U} \mathrm{L}^{-1}\right)$ & $\begin{array}{l}\text { A } \\
\text { B }\end{array}$ & $\begin{array}{l}7.1 \pm 0.42 \\
7.0 \pm 0.36\end{array}$ & $\begin{array}{l}7.2 \pm 0.42 \\
7.1 \pm 0.36\end{array}$ & $\begin{array}{l}0.63 \\
0.13\end{array}$ & 0.17 & 0.51 \\
\hline
\end{tabular}


over time in group A; however, total cholesterol and LDL cholesterol levels reportedly did not change. It is noteworthy that the addition of whey protein to the diet may have increased dietary fat as well as blood levels of cholesterol and LDL, but this change was made to both experimental groups. An increase in cholesterol after supplementing with whey protein has not been indicated in healthy persons $[5$, $7,12]$. In fact, studies in metabolically challenged populations (e.g., overweight or hypertensive participants) have shown that whey protein supplementation may help to lower cholesterol $[6,9]$. It may be speculated that the proteases in Aminogen ${ }^{\circledR}$ may interact with whey protein to produce a greater cholesterol-lowering effect than whey protein alone, possibly through the production of bioactive peptides. Oben [4] reported significant decreases in Creactive protein in a test group after an acute consumption of $5 \%$ and $10 \%$ Aminogen ${ }^{\circledR}$ blended with whey protein. Additionally, unpublished in vitro data have shown that Aminogen ${ }^{\circledR}$ hydrolyzes whey, soy, and casein proteins to produce peptides that inhibit angiotensin-converting enzyme, a mechanistic finding which may help to explain the divergent responses to diastolic blood pressure. These results suggest the possibility that the protease enzymes in Aminogen ${ }^{\circledR}$ may be producing bioactive peptides from whey protein that are not produced by endogenous protease enzymes. These peptides may help facilitate lower blood levels of total cholesterol and LDL cholesterol than peptides produced from whey protein by endogenous proteases leading to greater cardiovascular effects. Further studies may help to explain the significance of increased blood levels of total cholesterol and LDL cholesterol as well as increased diastolic blood pressure in the whey protein only group reported in this study. A more significant finding, however, may be that, as hypothesized, whey protein containing 3\% Aminogen ${ }^{\circledR}$ was well tolerated by subjects and results in no significant changes in hemodynamic parameters or markers of clinical safety for cardiovascular, calcium, liver, and kidney function when compared to whey protein alone. These findings are significant because of the lack of existing safety data on fungal enzymes when used as dietary supplements. While fungal enzymes have been used for many years in food processing and as food additives, the use of active fungal enzymes as dietary supplements is currently unregulated in many countries including the European Union member countries and Canada. This is primarily due to the lack of published clinical safety data. This study may help support the safety of repeated use of the fungal proteases in Aminogen ${ }^{\circledR}$ as a dietary supplement.

In conclusion, these results indicate that twice daily supplementation of $40 \mathrm{~g}$ whey protein containing $3 \%$ of the active fungal protease enzyme system Aminogen ${ }^{\circledR}$ was well tolerated during this 4-week study. The addition of Aminogen ${ }^{\circledR}$ to whey protein resulted in no adverse events and did not cause any measurable negative changes in various markers of clinical health. These, as well as previous results [4], support the safety and potential benefits of ingesting Aminogen ${ }^{\circledR}$ with an appropriate substrate such as whey protein. They also indicate further research regarding the combination of Aminogen ${ }^{\circledR}$ with protein-based foods and beverages is warranted.

Acknowledgments Thanks to Tim Ziegenfuss, PhD, FISSN, at the Center for Applied Health Sciences, Fairlawn, $\mathrm{OH}$, for serving as the PI for this study and Jennifer Hofheins, MS, RD, LD, at the Center for Applied Health Sciences, Fairlawn, $\mathrm{OH}$, for monitoring nutrition. Also, thanks to MK Laboratories, San Ramon, CA, for writing services and Chad M. Kerksick, PhD, of CMK Consulting, Norman, $\mathrm{OK}$, for writing services and data analysis on behalf of Triarco Industries. This study was funded by Triarco Industries, which manufactures and markets Aminogen ${ }^{\circledR}$.

Open Access This article is distributed under the terms of the Creative Commons Attribution Noncommercial License which permits any noncommercial use, distribution, and reproduction in any medium, provided the original author(s) and source are credited.

\section{References}

1. Suarez F, Levitt MD, Adshead J, Barkin JS (1999) Pancreatic supplements reduce symptomatic response of healthy subjects to a high fat meal. Dig Dis Sci 44:1317-1321

2. Wright R (2010) The enzyme market. Nutraceuticals World, June

3. Underkofler LA, Barton RR, Rennet SS (1958) Microbiological process report-production of microbial enzymes and their applications. Appl Microbiol 6:212-221

4. Oben J, Kothari SC, Anderson ML (2008) An open label study to determine the effects of an oral proteolytic enzyme system on whey protein concentrate metabolism in healthy males. J Int Soc Sports Nutr 5:10

5. Kerksick CM et al (2009) Early-phase adaptations to a split-body, linear periodization resistance training program in college-aged and middle-aged men. J Strength Cond Res 23(3):962-971

6. Pal S, Ellis V, Ho S (2010) Acute effects of whey protein isolate on cardiovascular risk factors in overweight, post-menopausal women. Atherosclerosis 212(1):339-344

7. Hayes A, Cribb PJ (2008) Effect of whey protein isolate on strength, body composition and muscle hypertrophy during resistance training. Curr Opin Clin Nutr Metab Care 11(1):40-44

8. Pal S, Ellis V, Dhaliwal S (2010) Effects of whey protein isolate on body composition, lipids, insulin and glucose in overweight and obese individuals. Br J Nutr 104(5):716-723

9. Pins JJ, Keenan JM (2006) Effects of whey peptides on cardiovascular disease risk factors. J Clin Hypertens 8(11):775-782

10. Beck TW et al (2007) Effects of a protease supplement on eccentric exercise-induced markers of delayed-onset muscle soreness and muscle damage. J Strength Cond Res 21(3):661-667

11. Buford TW et al (2009) Protease supplementation improves muscle function after eccentric exercise. Med Sci Sports Exerc 41:1908-1914

12. Campbell B et al (2007) International society of sports nutrition position stand: protein and exercise. J Int Soc Sports Nutr 4:8

13. Heidenreich PA, Trogdon JG, Khavjou OA, et al. (2011) Forecasting the future of cardiovascular disease in the United States. Circulation 2011; doi:10.1161/CIR.0b013e31820a55f5. Available at: http://circ.ahajournals.org 